Research Article

\title{
Evaluation of the Quality of Coastal Ecosystems in the Spermonde Archipelago Using Macroalgae as Indicators
}

\author{
Rispah Hamzah ${ }^{1}$, Luchman Hakim ${ }^{2}$, Catur Retnaningdyah 2* \\ ${ }^{1}$ Student of Biology Magister Study Program, Biology Departement, Faculity of Mathematics and Natural \\ Sciences, Universitas Brawijaya, Malang 65145, Indonesia \\ ${ }^{2}$ Department of Biology, Faculty of Mathematics and Natural Sciences, Universitas Brawijaya, Malang 65145, \\ Indonesia
}

Article history:

Submission Desember 2019

Revised January 2020

Accepted March 2020

*Corresponding author:

E-mail:

catur@ub.ac.id

\begin{abstract}
The quality of water in Spermonde Archipelago, South Sulawesi has decreased as a result of high human activities and land use, this can have an impact on the life of marine biota. Macroalgae is suitable for bioindicators because they live in a sessile manner, can accumulate metals and distributed widely. This research aimed to determine coastal ecosystem quality by using macroalgae as indicators on five islands that had different anthropogenic stresses. The research was carried out in April 2019 on Barrang Caddi, Bonebatang, Barrang Lompo, Kodingareng Keke, and Badi Islands. Community structures observed included taxa richness, diversity, evenness, dominance of macroalgae and physicochemical parameters (temperature, turbidity, $\mathrm{pH}$, salinity, DO, BOD, $\mathrm{H}_{2} \mathrm{~S}$, oil, grease, total Phosphate, and nitrate) as well as the measurement of the ecological condition using Quality of Rocky Bottoms (CFR) index. The results showed that physicochemical parameters (temperature, turbidity, $\mathrm{pH}$, salinity, $\mathrm{DO}, \mathrm{H}_{2} \mathrm{~S}$, oil, grease, total Phosphate) of the water still met the quality standards of sea water based on Decree of the State Minister for Environment No. 51/2004 for marine biota and other standards for macroalgae growth. BOD and nitrate have exceeded sea water quality standards for marine biota (20 mg/L for BOD and $0.008 \mathrm{mg} / \mathrm{L}$ for nitrates). A total of nine species of macroalgae were found in Barrang Caddi and Badi Island, three species in Bonebatang, and five species in Kodingareng Keke and Barrang Lompo Island. The result of Principal Component Analysis (PCA) and Biplot showed that physicochemical water quality has an influence on the macroalgae community structure. While the CFR index shows Barrang Caddi and Badi Island have poor ecological conditions and Bonebatang, Barrang Lompo, and Kodingareng Keke have bad ecological condition.
\end{abstract}

Keywords: Macroalgae, Spermonde Archipelago, water quality, CFR Index, Community structure

\section{Introduction}

Spermonde Archipelago are islands located on the west coast of South Sulawesi Province or southeast of the Makassar City, Indonesia [1, 2]. Administratively, these islands belong to the Barru Regency, Kepulauan Pangkajene Regency (Pangkep), Maros Regency, Makassar City and Takalar Regency [3]. This archipelago is also one of the regions with high diversity of ecosystems and marine life in Indonesia. There are 78 genera of macroalgae with a total of 262 species [2]. Some of the islands are populated and some are not. The availability of fresh water is one of the main factors that causes the island communities to settle on certain islands [3]. A short distance from the coast of Makassar causes the activity on the coast of Makassar to affect several small islands in the Spermonde Archipelago. The coastal city of Makassar has several functions including for the port of Pelni ships, inter-island traditional vessels, 


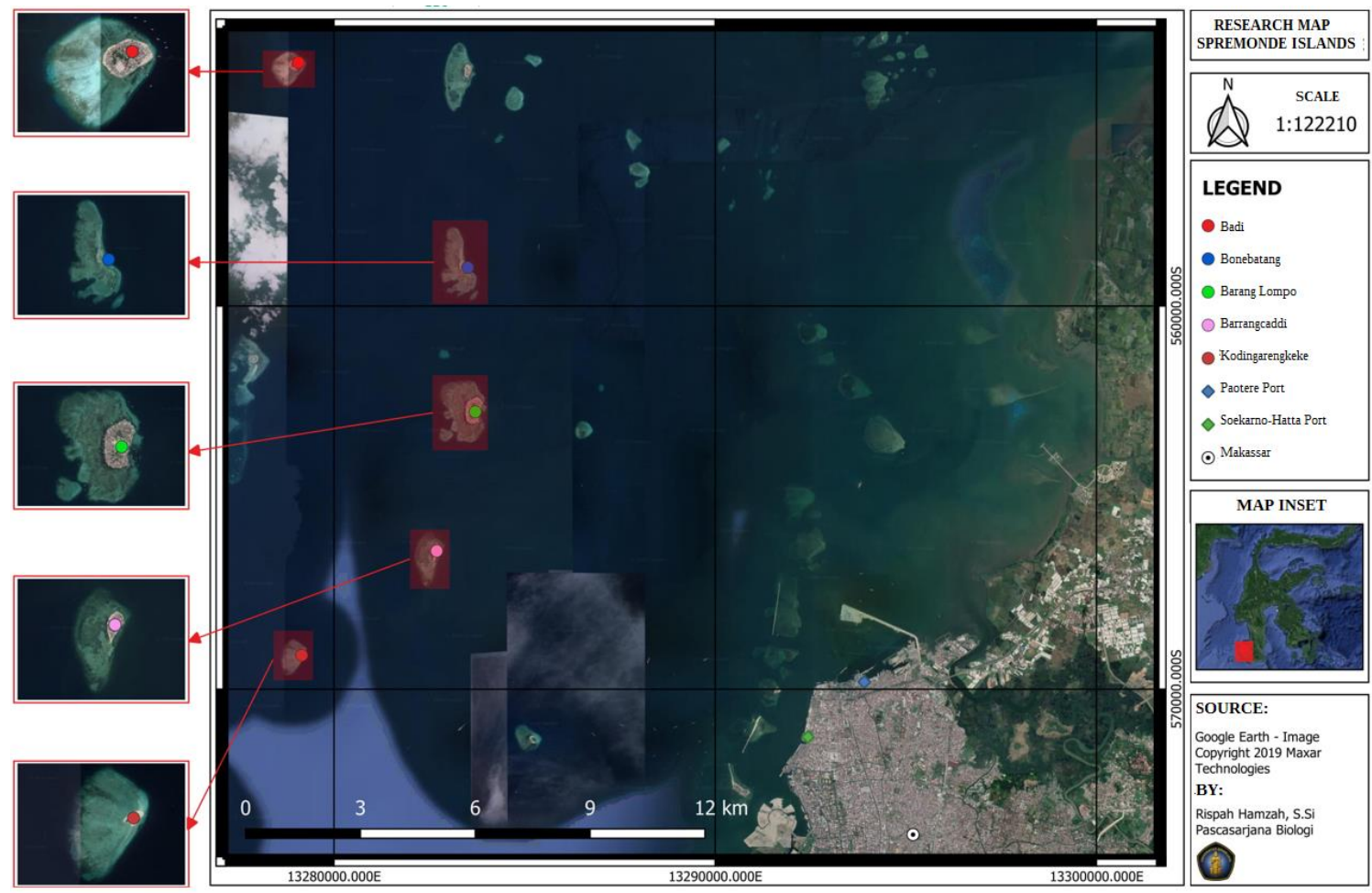

Figure 1. Study area in five islands in Spermonde Archipelago

fisheries, sea transportation routes, and tourist attractions. These activities cause changes in land use and contribute for nutrients and other toxic wastes to the water; thus, eutrophication often occurs $[4,5]$. This can trigger an increase in biomass as well as degradation and death of marine producers such as macroalgae thus can threaten the lives of another marine biota.

Prevention of Sea Air Pollution According to the Decree of the State Minister for the Environment No. 51 of 2004, concerning Sea Water Quality Standards, an objective evaluation method by physicochemical and biological methods are needed. Fish habitat communities such as macroalgae can be used as indicators of the health level of an ecosystem. This can happen due to the interaction between the seawater biota and its habitat, which is essentially a dynamic balance. Therefore, any changes in habitat and the contamination of pollutants into the water will affect the life and composition of biota [6].

Macroalgae is suitable for bioindicators because they live in a sessile manner, are easily identified, have a long-life span, exist in polluted locations, can accumulate metals and distributed widely [7]. Biomonitoring with macroalgae (passive biomonitoring) was first introduced in the early 1950s [7, 8] and is still widely used to assess the state of an environment [9].

Macroalgae are known as biological indicators in rocky coastal environments. Changes in macroalgae communities occur after prolonged exposure to nutrients or pollutants which eliminates the most sensitive macroalgae species among resistant species [10]. Several species of the Rhodophyta family are known to be potential bioindicators for chemical pollutants such as $\mathrm{Al}, \mathrm{As}, \mathrm{Br}, \mathrm{Cd}, \mathrm{Fe}, \mathrm{La}$, $\mathrm{Mn}, \mathrm{Ni}, \mathrm{Hg}, \mathrm{V}$, and Zn in Ghana [11], Cystoseira compressa species are known as bioindicators because they can accumulate heavy metals of $\mathrm{Cd}, \mathrm{Pb}$, $\mathrm{Cr}$, and $\mathrm{Hg}$ in the Mediterranean Sea [12].

Based on this background and also considering the development of the tourism sector and industrial activities in the coastal areas and small islands in the Spermonde Archipelagos, the water quality will be negatively impacted, therefore management needs to be done. It is necessary to evaluate the quality of the coastal water ecosystems of several islands in the Spermonde Archipelago, especially Barrang Caddi, Bonebatang, Barrang Lompo, and Kodingareng Keke Island. Hopefully, this research can produce recommendations for the development of ecotourism in the Spermonde Islands. 


\section{Material and Methods \\ Study area}

This research was conducted in April 2019 on five islands of Spermonde archipelago: (1) Barrang Caddi and Barrang Lompo Island located in the middle inner zone area, $5 \mathrm{~km}$ from the coast of Makassar city with a depth of $\pm 30 \mathrm{~m}$; (2) Bonebatang, Kodingareng Keke and Badi Island, located in the middle outer zone, are $12.5 \mathrm{~km}$ from the coast of Makassar city with a depth of $\pm 20-50 \mathrm{~m}$. The map of research locations can be seen in Figure 1.

\section{Sample collection}

The study used the Ex Post Facto method, a method for selecting a causal effect phenomenon that has been proved in the field (natural phenomena) thus researchers do not need to give any more treatment but only observe the effect on the dependent variable [13]. The basis of the research systemic approach is the complete causal correlation (causal finalist) of the object being assessed, namely environmental conditions such as variation of land use and community activities around the ecosystem of the coastal water to the macroalgae community structure and physicochemical quality of water. The dependent variables of this research were macroalgae community structure and water physicochemical parameters, while the independent variables were variations of land use and human activities.

A $50 \mathrm{~m}$ transect line was performed perpendicularly (vertical) to the coastline [13]. Five quadrants $\left(1 \times 1 \mathrm{~m}^{2}\right)$ were placed along the transect line, and three replicates were used in this sampling method for each station. The number of each macroalgae species were counted in each quadrant. Samples that have been collected were taken to Hasanuddin University Marine station laboratory.

The water quality of each station was measured in three replicates. The physicochemical parameters (DO, $\mathrm{pH}$, salinity, and temperature) of the seawater were measured in situ. Bottles of seawater were collected in each sampling point. The concentration of BOD, nitrate, total phosphate (TP), $\mathrm{H}_{2} \mathrm{~S}$, oil, grease, and $\mathrm{Pb}$ in water were measured at Makassar Health Laboratory Center. The physicochemical parameters of seawater tested in this study, as well as the measurement methods and analysis standards used, are presented in Table
Table 1. Water physics chemical were measured in this research

\begin{tabular}{lll}
\hline Parameters & Unit & Methods \\
\hline $\mathrm{pH}$ & - & $\mathrm{pH}$ meter \\
Dissolved Oxygen (DO) & $\mathrm{mg} / \mathrm{L}$ & DO meter \\
Salinity & $\%$ oo & Refractometer \\
Turbidity & $\mathrm{NTU}$ & Turbidimeter \\
BOD & $\mathrm{mg} / \mathrm{L}$ & Winkler \\
Nitrate & $\mathrm{mg} / \mathrm{L}$ & Colorimetric \\
Phosphate & $\mathrm{mg} / \mathrm{L}$ & Colorimetric \\
Sulfide as $\mathrm{H}_{2} \mathrm{~S}$ & $\mathrm{mg} / \mathrm{L}$ & Colorimetric \\
Oil and Grease & $\mathrm{mg} / \mathrm{L}$ & Gravimetric \\
Lead $(\mathrm{Pb})$ & $\mathrm{mg} / \mathrm{L}$ & AAS \\
\hline
\end{tabular}

Table 2. Numerical scoring system for the assignment of the ecological status of each sampling station

\begin{tabular}{cc}
\hline CFR Values & Status \\
\hline $83-100$ & High \\
$62-82$ & Good \\
$41-61$ & Moderate \\
$20-40$ & Poor \\
0.19 & Bad \\
\hline
\end{tabular}

1. Data analysis of the results of measurements in situ and the results of laboratory analysis of water quality parameters are carried out descriptively, by comparing the results obtained with the quality standards of sea water based on Decree of the State Minister for Environment No. 51/2004 for marine biota.

\section{Data analysis}

The results of macroalgae structure and water quality analysis were analyzed using Ms. Excel. Macroalgae structure was represented by determining the Shannon-Wiener Diversity index $\left(\mathrm{H}^{\prime}\right)$, Evenness index (E), Dominance index (D), and taxa richness (S). Macroalgae structure and water quality data were analyzed by biplot using the PAST 3.20 program.

\section{Assessment of environmental quality}

Environmental quality was assessed by determining the Quality of Rocky Bottoms index (CFR index) [14] (Table 2). It provides a quantitative approach for reflecting, in a homogeneous way, the ecological condition of hard substrate habitats throughout the extent of the water bodies (Eq. 1) [15].

$$
C F R=R+C+O+S \ldots(1)
$$


Note:

$\mathrm{R}$ : Richness

$\mathrm{O}$ : Presence of Opportunistic species

C : Abundance (Cover)

S : Physiological status

This index describes the suitability of benthic macrophytes as indicators of the effects of different pollution gradients.

\section{Results and Discussion \\ Macroalgae community structure}

In five study areas, 15 species of macroalgae were found consisting of seven species of green algae (Chlorophyceae), five species of brown algae (Phaeophyceae), and three species of red algae (Rhodophyceae). The location that had the highest number of Taxa Richness was station 1 (Barrang Caddi), with nine species, and the lowest was station 2 (Bonebatang), with three species (Figure 2). Station 2 with substrate structure that was less varied, caused the species of algae found to be less varied. On the other hand, station 1 (Barrang Caddi) had a varied combination of substrate structure so that the species of macroalgae found also varied. The types of substrate found were sand and broken coral fragments at station 1 , while at station 2 (Bonebatang) the type of the substrate was fine sand

Based on Figure 2 it can be seen that three species are Padina australis, Dictyota dichotoma, and Chlorodesmis fastigiata was found in 2 stations (Barrang Caddi and Badi) with high dominance (Figure 2). This was possible because the location of the study has characteristics suitable for the growth of Padina sp. Seaweed is a macro-algae that has a macroscopic size and grows on rocky and sandy substrates. Other macroalgae species that occupied sand substrates and broken coral fragments were Boergesenia forbesii, Sargassum binderii, and Halimeda sp., this was because these macroalgae have a disc-shaped holdfast structure that can attach to the substrate. One of the important components that play an important role in the growth and presence of macroalgae species is the substrate. Type of bottom substrate affects the type of benthic organisms that live on the surface. Not only that, the distribution and abundance of macroalgae communities in intertidal rocky shores are affected by various abiotic variables such as

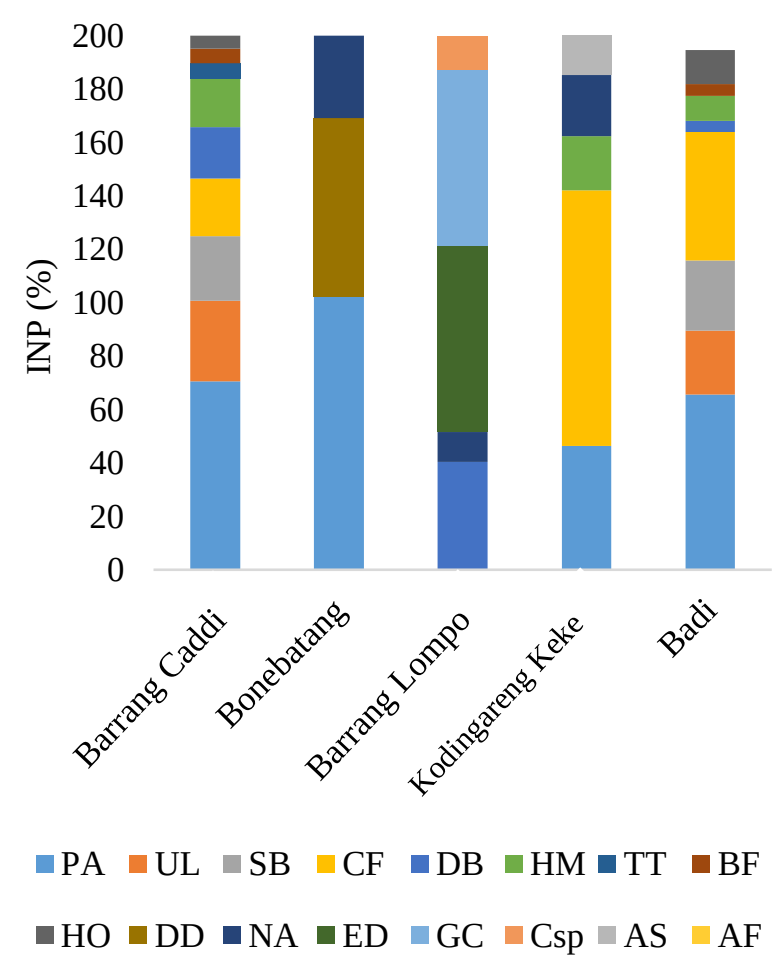

Figure 2. Measurement importance value index of macroalgae in each station

Note: PA: P. australis; UL: U. lactuca; SB: S. binderi; CF: C. fastigiate; DB: D. bartayresiana; HM: $H$. macroloba; TT: T. ornata; BF: B. forbesii; HO: $H$. opuntia; DD: D. dichotoma; NA: N. annulate ED: E. denticulatum; GC: G. coronopifolia; C sp: Chlorodesmis sp.; AS: A. spicifera;

tidal regimes, wave action, nutrient levels, substrate stability, desiccation, and sedimentation [16, 17].

The size distribution of sediment particles greatly influences the pore water exchange in the holdfast macroalgae section with the water column at the top. In the particle size distribution in the direction of dust and clay (terrigenous), it will cause the exchange of pore water with water column to below, the opposite condition will be experienced by macroalgae if it occupies the type of coarse sand sediments, fractures and rubble (carbonates) where the pore water exchange with the water column very high with currents that carry nutrients (nutrients) for the growth and development of macroalgae [18, 19].

The type of macroalgae species found at the study area was relatively less varied (Table 3), compared to another research that found 28 ma- 


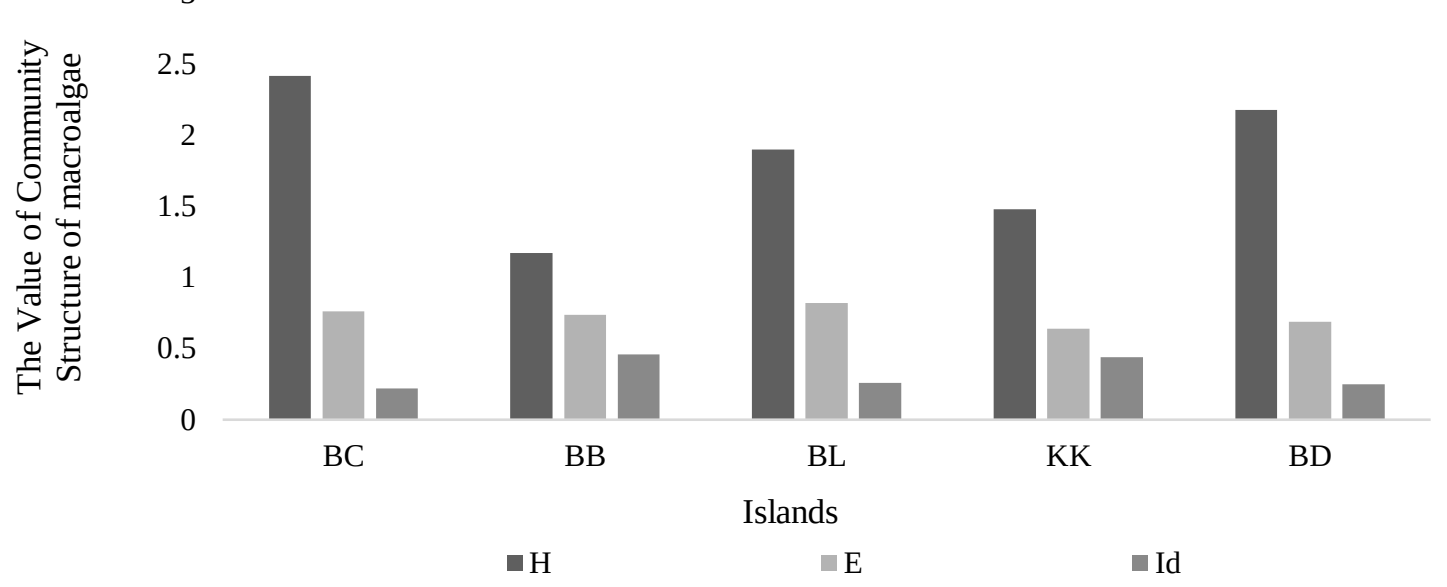

Figure 3. Histogram of diversity index ( $\left.\mathrm{H}^{\prime}\right)$, Evenness index (E) and dominance index (D) of macroalgae at five study area (Note: $\mathrm{BC}=$ Barrang Caddi, BB= Bonebatang, $\mathrm{BL}=$ Barrang Lompo, KK= Kodingareng Keke, and $\mathrm{BD}=\mathrm{Badi})$

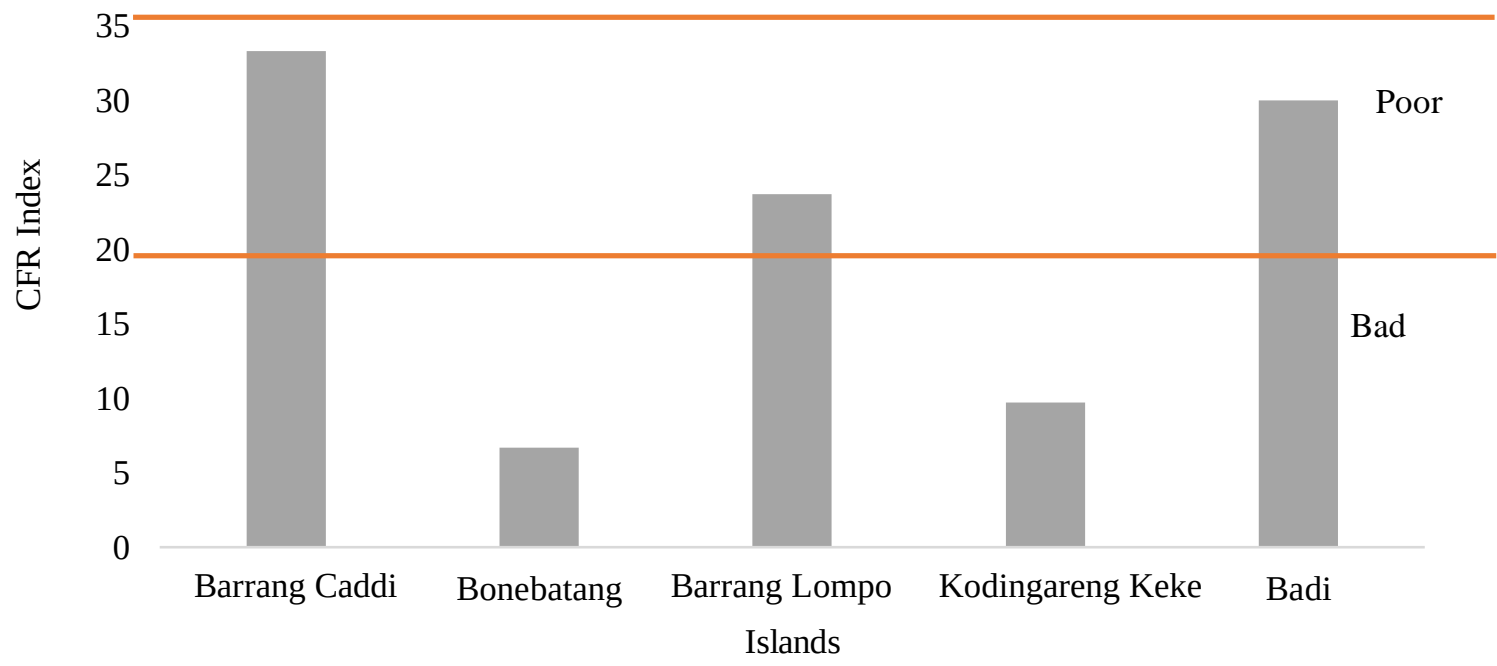

Figure 4. Measurement of ecological condition by use CFR index in five islands

croalgae species on the water of Barrang Lompo and Bonebatang Islands [2]. This is due to different natural conditions which of course have different environmental factors that affects the presence of macroalgae.

Based on Figure 3, the analysis of macroalgae community structure in five study areas showed that the highest diversity value $\left(\mathrm{H}^{\prime}=2.42\right)$ was found at station 1 (Barrang Caddi) with low dominance index. This was due to the subtraction condition which was dominated by sand, dead coral and vast sea grass beds. Another study stated that the condition of the substrate dominated by sand and coral fragments supports the growth and development of macroalgae. Another factor was the human activities in the area close to the habitat of macroalgae [20]. The growth and survival of macroalgae were supported by the stability of the substrate as a place to grow. Daily human activities can cause pressure on the presence and diversity of seaweed (algae) [21]. The diversity value at station 2 (Bonebatang) was low due to the high dominance of a species, and also because the island was a small uninhabited island without any nutrient input that could support macroalgae growth.

Diversity is a very important parameter to compare various marine biota communities, especially to determine the effect of water quality. This index value was influenced by the number of individuals of each species of macroalgae and the total number of individuals of all species of macroal- 
Table 4. Water physico-chemical paramaters were measured

\begin{tabular}{|c|c|c|c|c|c|c|}
\hline \multirow{2}{*}{ Parameter } & \multicolumn{5}{|c|}{ Observation result } & \multirow{2}{*}{ Standard* } \\
\hline & $\mathrm{BC}$ & BB & $\mathrm{BL}$ & KK & $\mathrm{BD}$ & \\
\hline Temperature $\left({ }^{\circ} \mathrm{C}\right)$ & $31.05 \pm 0.17 \mathrm{a}$ & $31 \pm 0 \mathrm{a}$ & $32.44 \pm 0.68 b$ & $30.55 \pm 0.39 a$ & $33.08 \pm 0.4 \mathrm{~b}$ & $28-30$ \\
\hline Salinity $(\%$ oo $)$ & $30 \pm 0 a b$ & $30 \pm 0 \mathrm{ab}$ & $30 \pm 0 a b$ & $29.3 \pm 0.1 \mathrm{a}$ & $30.2 \pm 0.04 b$ & $33-34$ \\
\hline Turbidity (ms) & $0.87 \pm 0.24 \mathrm{ab}$ & $0.64 \pm 0.14 \mathrm{a}$ & $1.26 \pm 0.57 \mathrm{~b}$ & $0.63 \pm 0.22 \mathrm{a}$ & $0.75 \pm 0.09 \mathrm{ab}$ & $<5$ \\
\hline $\mathrm{pH}$ & $8.08 \pm 0.07 \mathrm{ab}$ & $8.19 \pm 0.02 b$ & $8.32 \pm 0.06 c$ & $7.99 \pm 0.11 \mathrm{a}$ & $8.38 \pm 0.03 c$ & $7-8.5$ \\
\hline DO (mg/L) & $4.80 \pm 0.29 a$ & $4.63 \pm 0.08 \mathrm{a}$ & $6.10 \pm 0.92 b$ & $4.95 \pm 0.56 a$ & $7.70 \pm 0.41 c$ & $>5$ \\
\hline BOD (mg/L) & $26.12 \pm 3.49 \mathrm{a}$ & $25.39 \pm 3.83 a$ & $28.33 \pm 2.92 \mathrm{a}$ & $28.70 \pm 2.71 \mathrm{a}$ & $29.81 \pm 0 \mathrm{a}$ & 20 \\
\hline Nitrate (mg/L) & $0.03 \pm 0.01 \mathrm{a}$ & $0.06 \pm 0.01 \mathrm{a}$ & $0.16 \pm 0.38 \mathrm{a}$ & $0.05 \pm 0.01 \mathrm{a}$ & $0.1 \pm 0.02 \mathrm{a}$ & 0.008 \\
\hline
\end{tabular}

gae. The diversity index in the study area was in the medium category (greater than 1 smaller than 3). This study showed that the diversity index value was directly proportional to the evenness index and inversely proportional to the dominance index. According to Shannon Wiener, the index value of $\mathrm{H}^{\prime}=1.0-3.0$ indicates that the species diversity in an area of water was categorized as medium diversity [22]. The value of (id) $=<0.5$ indicates low dominance, while (id) $=1$ indicates high dominance. Stable Evenness index indicates that the number of individuals of each macroalgae found was not so different. This is also proved by the low dominance value (no dominant species). The evenness of macroalgae species in water indicated that the macroalgae can grow optimally. Macroalgae can grow optimally because of good water conditions and stable environmental factors. The diversity of organisms in water is strongly influenced by environmental factors. Macroalgae communities that have high biodiversity values generally found good water conditions, and vice versa, poor water conditions will result in lower diversity [23].

\section{Quality of rocky bottoms index (CFR Index)}

The CFR assessment results showed that Barrang Caddi and Badi Island have 'poor' ecological status (CFR value $=30-33.3)$, which means that both regions (Barrang Caddi and Badi) were anthropogenic region. Bonebatang, Kodingareng Keke, and Barrang Lompo Island have 'bad' ecological status (CFR value $=6.7-23.7)$, which means that these regions have started to be highly polluted (Figure 4). This was caused by an increase of human activities on those islands, thus affecting the richness and abundance of macroalgae. On the other hand, Barrang Lompo Island is one of the islands in the Spermonde Archipelago that has an increasing population, especially in the last two decades. High human activity causes changes in the environment where the sea is used as a place to dispose unhandled waste. This also has an impact on the high BOD content in the water, proving that the high content of organic pollutants in this area was a result of human activities. This will cause coastal erosion and disturb macroalgae and another biota.

\section{Water physicochemical quality}

Macroalgae growth is influenced by environmental factors both physical and chemical. The results of monitoring water coastal quality in five islands i.e. Barrang Caddi, Bonebatang, Barrang Lompo, Badi and Kodingareng Keke showed that total phosphate in all coasts $<0.010 \mathrm{mg} / \mathrm{L}, \mathrm{H}_{2} \mathrm{~S}<$ $0.01 \mathrm{mg} / \mathrm{L}$, oil and grease $<0.1 \mathrm{mg} / \mathrm{L}$, and $\mathrm{Pb}<$ $0.005 \mathrm{mg} / \mathrm{L}$. These concentrations still met quality standards of sea water based on Decree of the Indonesia State Minister for Environment No. 51/2004 for marine biota. The variation value of common other physics chemical parameters of water such as $\mathrm{pH}$, temperature, salinity, dissolved oxygen (DO) Biological oxygen demand (BOD) and Nitrate is shown in Table 4.

The water temperature in the five study areas did not differ much and fluctuated not too large, from $30-33^{\circ} \mathrm{C}$ (Table 3), with the lowest tempera- 
ture at the station 4 (Kodingareng Keke) with an average of $30.55^{\circ} \mathrm{C}$. The highest temperature range values are in the Station 5 (Bonebatang), an average of 33.08 compared to the quality standard value, the highest temperature value has exceeded the quality standard $\left(>30^{\circ} \mathrm{C}\right)$, is a normal range for growth Macroalgae and another organism. Generally, as stated that a good temperature range for macroalgae growth ranges from $21-32.4^{\circ} \mathrm{C}$ [24].

Turbidity is a limiting factor for the process of photosynthesis and primary production because it affects the penetration of light where the turbidity of the waters is a description of the optical properties of a water medium that is determined based on the number of light rays emitted and absorbed by particles in the water column $[25,26]$. Based on Table 2, the Turbidity value in the study area ranged from 0.62 NTU to 1.26 NTU. The high turbidity value in the middle inner zone area is Barrang Lompo Island (BL) with an average of 1.26 NTU \pm 0.57 while the outer middle zone area is around $0.63 \mathrm{NTU} \pm 0.22$. The high turbidity value in the area of the middle inner zone is suspected that the waters received a lot of suspended material input originating from land sedimentation (organic particles of mud) and anthropogenic waste.

Salinity in the five islands has a value that is not much different from the measured salinity value ranging from $29.3-30.1 \%$. Salinity in these waters still matches the salinity values found in coastal areas. Generally, the range of good salinity for macroalgae growth and development is 15 - 38 $\%$. Salinity plays an important role in the life of macroalgae, salinity that is too high or too low will cause interference with the physiological process $[27,28]$.

The degree of acidity $(\mathrm{pH})$ in these waters ranges from 7.91-8.18, still good for Macroalgae life. Macroalgae growth can take place continuously in the $\mathrm{pH}$ range of 7-8. The $\mathrm{pH}$ range $<6.5$ will suppress the growth rate even $\mathrm{pH}<9$ is the optimal range in water. The range of $\mathrm{pH}$ values in these waters is still within the safe limits for the $\mathrm{pH}$ of an aquatic, generally, the $\mathrm{pH}$ of seawater is relatively stable in the range of 7.99-8.38 [29].

The results of measurements of dissolved oxygen (DO) content from 5 research locations ranged from $4.63 \mathrm{mg} / \mathrm{L}$ to $7.70 \mathrm{mg} / \mathrm{L}$. The low DO concentration at 3 research stations (Bonebatang, Barrang Caddi, and Kodingareng Keke) is related to the low abundance of organisms and the high content of pollutants in the waters. While the DO measurement results for two stations (Barrrang Lompo and Badi) have met the quality standard for the growth of Macroalgae which is $>5 \mathrm{ppm}$ [30]. Generally, the oxygen content of $5 \mathrm{ppm}$ with water temperatures ranging from $20-30^{\circ} \mathrm{C}$ is still relatively good for fish life, even if there are no toxic compounds in the water, the oxygen content of $2 \mathrm{ppm}$ is sufficient to support the life of aquatic organisms [31].

Biochemical oxygen demand (BOD) is one of the most important and widely used parameters for characterizing the organic pollution of water and wastewater, which is estimated by determining the amount of oxygen required by aerobic microorganisms for degrading organic matters in wastewater. BOD is a measure of pollutants from waste in the water. The greater the BOD concentration of water shows the concentration of organic matter in the water is also high [32]. The highest BOD concentration was found on Badi Island (Station 5) of $29.81 \mathrm{mg} / \mathrm{L}$ and the lowest concentration was found on Bonebatang Island (Station 2). BOD concentrations at all points are higher than the established quality standard of at least $20 \mathrm{mg} / \mathrm{L}$, meaning that the organic content in the waters is more than what is needed by marine biota. This condition can endanger marine biota due to high levels of natural pollutants in water.

Nitrate is the main form of Nitrate is the main nutrient that supports the growth and development of Macroalgae. Nitrate levels in this transfer are between 0.03-0.16 mg/L. with the highest concentration found in the central middle zone, Barrang Lompo Island (Station 3), rated $0.16 \mathrm{mg} / \mathrm{L}$ and Badi Island (Station 5) the value is $0.1 \mathrm{mg} / \mathrm{L}$. The high concentration of nitrate in the 2 study locations was caused by the majority of households that had accumulated at this station. Besides, this station also receives a supply of nutrients through the household liquid waste stream. Anthropogenic activity on land increases the supply of nutrients for coastal eutrophication that can be achieved in Coastal eutrophication [33, 34].

High nitrate concentrations in both locations caused the dominance of $D$. bartayresiana macroalgae species, E. denticulatum, G. coronopifolia, Padina australis, dan C. fastigiata (Table 3). Bonebatang island location (station 2) nitrate concentration value is $0.06 \mathrm{mg} / \mathrm{L}$ and the lowest is 

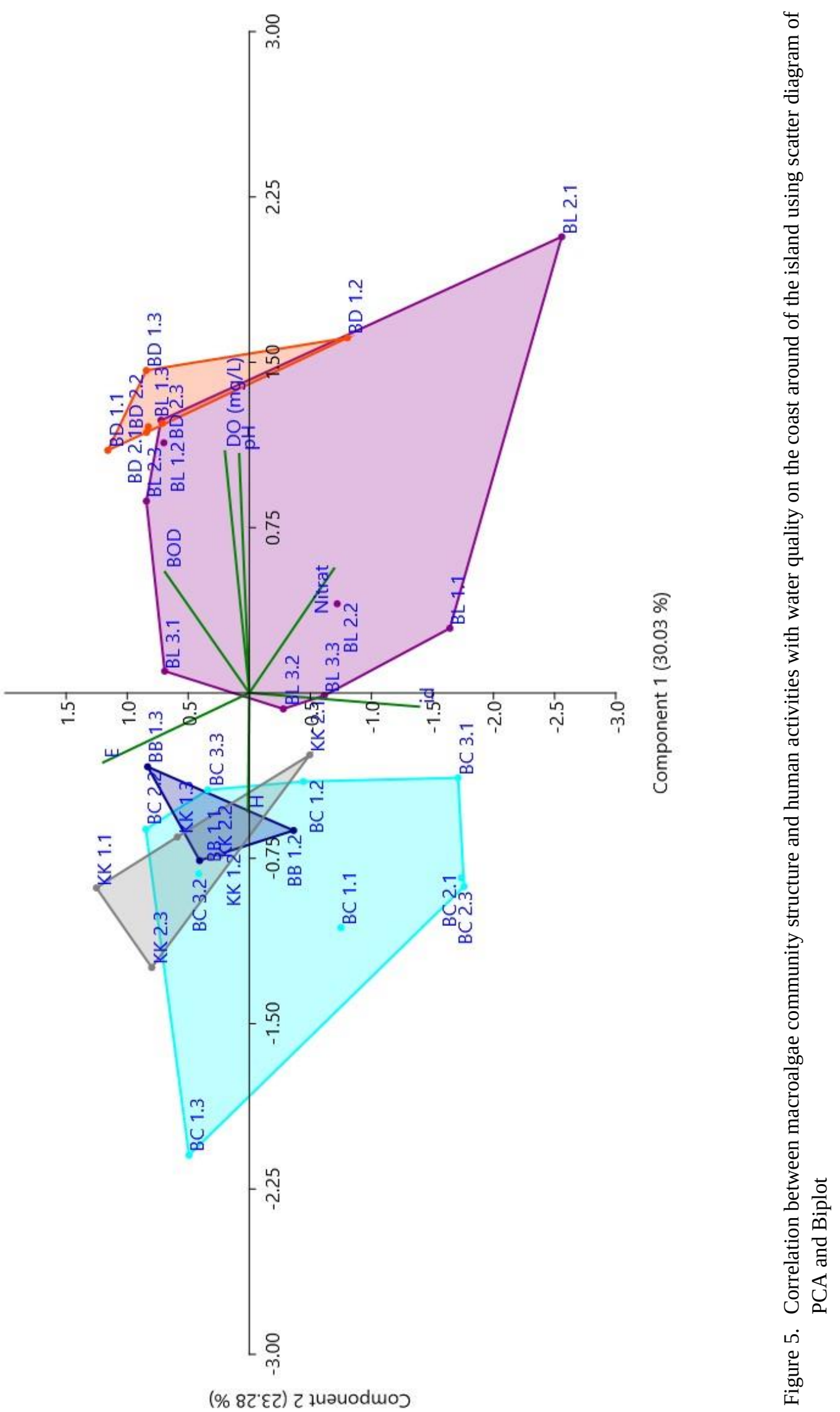

(\% 8ح'દ乙) z łuәuodwoว 
Kodingareng Keke island location (station 4) concentration value $0.05 \mathrm{mg} / \mathrm{L}$. Low nitrate concentration for Bonebatang and Kodingareng Keke island locations is associated with all locations that are far from being involved in land activities such as organic waste disposal. Based on the results of the study the range of values for nitrate concentrations is still a good normal category for macroalgae growth. The water threshold value determined by US-EPA (1973) [35] for nitrates is $0.07 \mathrm{mg} / \mathrm{L}$.

\section{Correlation between macroalgae community structure and water quality in in the beach of the study area}

Correlation between Macroalgae Community Structure and water Quality was verified. The result of the PCA analysis showed that physicochemical water quality has an influence on the macroalgae community structure (Figure 5). Barrang Lompo and Badi Island with mildly polluted waters were characterized by the dominant species of macroalgae with high Nitrate and BOD. Whereas Barrang Caddi Island with good physicochemical water quality was characterized by high diversity ( $\left.\mathrm{H}^{\prime}\right)$ and Evenness (E) index. Macroalgae in the tropics especially eastern part of Indonesia has high species diversity, but algae are very susceptible to changes in the environment or ecological pressure that can affect its existence. Environmental influences such as substrate, water movement, temperature, salinity, tides, light, $\mathrm{pH}$, nutrients and water quality will because damage and even species extinctions [36, 37].

This research results proved that some indices of macroalgae could be used for monitoring the impact of human activity and land use on water quality in some beach. This evaluation could then be served as basis recommendations for the development of ecotourism and coastal ecosystem management in Spermonde Archipelago.

\section{Conclusion}

This study showed macroalgae can use as bioindicators. Barrang Caddi island has the better ecological condition than other islands. This is indicated by the high value of H' (2.42) evenness index $(0.76)$, nitrate $(0.03 \mathrm{mg} / \mathrm{l})$ and dominance index (0.22). Barrang Lompo island with the highest nitrate and bod categorize as mildly polluted. However, this physicochemical the results showed (temperature, turbidity, $\mathrm{DO}$ and $\mathrm{pH}$,) in this study area still met the quality standards of sea waterbased on the decree of the state minister for the environment no. 51/2004 for marine biota and other standards. BOD and nitrate concentrations at all points are higher than the established quality standard. The result of the PCA analysis showed that physicochemical water quality has an influence on the macroalgae community structure. While CFR index show Barrang Caddi island and Badi island have poor ecological condition and Bonebatang, Barrang Lompo, and Kodingareng Keke have a bad ecological condition.

\section{Acknowledgment}

The authors would like to thanks the funders of this research namely Directorate General of Higher Education the Ministry of Research, Technology and Higher Education of Indonesia which has given a national research grant "Hibah Tesis Magister 2019”.

\section{References}

1. Erftemeijer PLA, Middelburg JJ (1993) Sediment-nutrient interactions in tropical seagrass beds: a comparison between a terrigenous and a carbonate sedimentary environment in South Sulawesi (Indonesia). Marine Ecology Progress Series 102 187189.

2. Amri K (2012) Sinekologi padang lamun akibat tekanan antropogenik: studi kasus Pulau Barrang Lompo dan Bonebatang Kepulauan Spermonde Sulawesi Selatan. Institut Pertanian Bogor

3. Chandra W (2013) Ekosistem Laut Kepulauan Spermonde Rusak Parah. https://www.mongabay.co.id/2013/07/24/ekosistemlaut-kepulauan-spermonde-rusak-parah/. Accessed: October 2019.

4. Langoy ML., Saroyo S, Dapas FN. et al. (2012) Deskripsi Alga Makro di Taman Wisata Alam Batuputih, Kota Bitung. JURNAL ILMIAH SAINS 11 (2): 219. doi: 10.35799/jis.11.2.2011.210.

5. Litaay C (2014) Distribution and Diversity of Macro Algae Communities in the Ambon Bay. J Ilmu dan Teknol Kelaut Trop. doi: 10.29244/jitkt.v6i1.8636

6. Indriana I (2003) Pengaruh Pengkayaan Nutrien Nitrogen dan Fosfor Terhadap Pola Pertumbuhan dan Keanekaragaman Perifiton Sungai Brantas Bagian Hulu. Universitas Brawijaya

7. García-Seoane R, Fernández JA, Villares R, Aboal JR (2018) Use of macroalgae to biomonitor pollutants in coastal waters: Optimization of the methodology. Ecological Indicators 84 710-726. doi: 10.1016/J.ECOLIND.2017.09.015.

8. Rainbow PS, Phillips DJH (1993) Cosmopolitan biomonitors of trace metals. Marine Pollution Bulletin 26 (11): 593-601. doi: 


\subsection{6/0025-326X(93)90497-8.}

9. Gubelit YI, Kovalchuk NA (2010) Macroalgal blooms and species diversity in the Transition Zone of the eastern Gulf of Finland. Hydrobiologia 656 (1): 83-86. doi: 10.1007/s10750-0100425-2.

10. Desrosiers C, Leflaive J, Eulin A, Ten-Hage L (2013) Bioindicators in marine waters: Benthic diatoms as a tool to assess water quality from eutrophic to oligotrophic coastal ecosystems. Ecological Indicators $32 \quad 25-34 . \quad$ doi 10.1016/J.ECOLIND.2013.02.021.

11. Serfor-Armah Y, Nyarko BJB, Osae EK et al. (2001) Rhodophyta Seaweed Species as Bioindicators for Monitoring Toxic Element Pollutants in the Marine Ecosystem of Ghana. Water, Air, and Soil Pollution 127 (1/4): 243-253. doi: 10.1023/A:1005271005093.

12. Benfares R, Seridi H, Belkacem Y, Inal A (2015) Heavy Metal Bioaccumulation in Brown Algae Cystoseira compressa in $\mathrm{Al}-$ gerian Coasts, Mediterranean Sea. Environmental Processes 2 (2): 429-439. doi: 10.1007/s40710-015-0075-5.

13. English S, Wilkinson C, Baker V (1997) Survey Manual for Tropical Marine Resources 2nd ed. Townsville, Australian Institute of Marine Science.

14. Hydraulics) G (Group of SO and E (2005) Caracterización, Ana'lisis de Presiones e Impactos y Evaluación del estado de las masas de agua costeras de Cantabria. Technical Report University of Cantabria-Environment Department, Regional Government of Cantabria, Santander, Spain. www.dmacantabria.com. Accessed: October 2019.

15. Juanes JA, Guinda X, Puente A, Revilla JA (2008) Macroalgae, a suitable indicator of the ecological status of coastal rocky communities in the NE Atlantic. Ecological Indicators 8 (4): 351-359. doi: 10.1016/J.ECOLIND.2007.04.005.

16. Dawes CJ (1998) Marine botany. New York, John Wiley.

17. Pratama W, Dewi SC, Sari IZR et al. (2015) Distribution and Abundance Macroalgae in Intertidal Zone Beach, Gunung Kidul, DIY. In: Setyobudi RH, Nuringtyas SR, Burlakovs J, et al. eds Int. Conf. Biol. Sci. Yogyakarta, KnE Publishing. pp 514-517.

18. Huettel M, Gust G (1992) Impact of Bioroughness on Interfacial Solute Exchange in Permeable Sediments. Marine Ecology Progress Series 89 253-267.

19. Schutte CA, Ahmerkamp S, Wu CS et al. (2019) Biogeochemical Dynamics of Coastal Tidal Flats. In: Perillo GME, Wolanski E, Cahoon DR, Hopkinson CS eds Coast. Wetl., 2nd ed. New York, Elsevier. pp 407-440.

20. Priosambodo D, Ferial EW (2006) Analisis Vegetasi Makroalgae Di Rataan Terumbu Karang Pulau Katindoang Kecamatan Sinjai Utara Kabupaten Sinjai. Bioma 1 (2): 31-45.
21. Kadi A (2004) Potensi Rumput Laut di Beberapa Perairan Pantai di Indonesia. Oseana 4 25-36.

22. Romimohtarto K, Juwana S (2001) Biologi Laut. Ilmu Pengetahuan Tentang Biota Laut. Jakarta, Djambatan.

23. Namakule U, Rehena JF, Rumahlatu D (2017) Seagrass community structure in various zones in coastal waters of Haya village, Central Moluccas district.

24. Dawes CJ (1981) Marine botany. New York, John Wiley and Sons.

25. Boyd CE (2015) Water Quality. doi: 10.1007/978-3-319-174464

26. Tosic M, Narváez-Flórez S, Parra JP (2013) Selection of parameters in the design of beach coastal water quality monitoring programs. Intropica 8 43-51.

27. Lüning K, Yarish C, Kirkman H (1990) Seaweeds : their environment, biogeography, and ecophysiology. Wiley.

28. Short FT, Coles RG (2001) Global seagrass research methods. Elsevier.

29. Evans L V., Hoagland KD, Phycological Society of America., American Institute of Biological Sciences. (1986) Algal biofouling. Elsevier.

30. Keputusan Menteri Negara Lingkungan Hidup Nomor 537. Keputusan Menteri Negara Lingkungan Hidup Nomor 51 (2004) Tentang Baku Mutu Air Laut. Jakarta, Menteri Negara Lingkungan Hidup.

31. Riva’i RW, Pertagunawan K (1983) Biologi Perikanan. Jakarta, CV Kayago.

32. Salmin (2005) Oksigen Terlarut (DO) dan Kebutuhan Oksigen Biologi (BOD) sebagai Salah satu Indikator untuk Menentukan Kualitas Perairan. Oseana 30 (3): 21-26.

33. Lapointe BE (1997) Nutrient thresholds for bottom-up control of macroalgal blooms on coral reefs in Jamaica and southeast Florida. Limnology and Oceanography 42 (5part2): 1119-1131. doi: 10.4319/lo.1997.42.5_part_2.1119.

34. Piñón-Gimate A, Páez-Osuna F, Serviere-Zaragoza E, CasasValdez M (2012) Macroalgal blooms in coastal lagoons of the Gulf of California eco-region: A summary of current knowledge. Botanica Marina 55 (2): 129-142. doi: 10.1515/BOT.2011.101.

35. Environmental Protection Agency (1972) Water Quality Criteria. Washington, D.C., The Environmental Protection Agency.

36. Atmadja WS (1996) Pengenalan jenis-jenis rumput laut Indonesia. Jakarta, Puslitbang Oseanologi-LIPI.

37. Dwimayasanti R, Kurnianto D (2018) Komunitas Makroalga di Perairan Tayando-Tam, Maluku Tenggara. Oseanologi dan Limnologi di Indonesia 3 (1): 39 doi: 10.14203/oldi.2018.v3i1.82. 